\title{
Audit on maternal mortality in a tertiary care centre in India of 6 years, a retrospective analysis
}

\author{
Neha Agrawal, Hemangi K. Chaudhari*
}

Department of Obstetrics and Gynecology, Seth GS Medical College, KEM Hospital Mumbai, Maharashtra, India

Received: 17 December 2019

Accepted: 23 December 2019

*Correspondence:

Dr. Hemangi K. Chaudhari,

E-mail: hemangichaudharik@gmail.com

Copyright: (c) the author(s), publisher and licensee Medip Academy. This is an open-access article distributed under the terms of the Creative Commons Attribution Non-Commercial License, which permits unrestricted non-commercial use, distribution, and reproduction in any medium, provided the original work is properly cited.

\begin{abstract}
Background: This study is carried out on 382 cases of maternal deaths from July 2010 to June 2016 at the department of obstetrics and gynaecology of tertiary centre to evaluate causes and risk factor associated with maternal deaths.

Methods: Retrospective analysis of all maternal deaths occurred in department of obstetrics and gynaecology of tertiary care hospital from July 2010 to June 2016.

Results: The MMR in the study period was 915/100000 live births. Maximum no. of maternal death $42.7 \%$ were in age group of 21-25 years, majority of them residing in urban area. 117 patients referred from sub-district/district hospital. $76.4 \%$ patients were registered. $60 \%$ maternal deaths were seen in postnatal period. In present study majority of maternal deaths $60 \%$ were due to indirect cause while $40 \%$ patients died due to direct cause. Major causes of maternal deaths were hypertensive disorder $12 \%$, obstetric haemorrhage $11 \%$ tuberculosis $11 \%$, hepatitis $\mathrm{E} 8 \%$ and pregnancy related infections $5.6 \%$.

Conclusions: High maternal mortality can be due to the fact that the study was conducted in tertiary care referral centre. Referral of moribund cases from rural, sub-district, district and peripheral hospital to our institute have inflated this mortality ratio. All of these being preventable causes of death can be avoided by improving standard of obstetric care, increasing number of health professionals, upgradation of healthcare facilities at first referral units and by making better health policies.
\end{abstract}

Keywords: Direct cause, Health facilities, Indirect cause, Intervention, Maternal deaths, Referral

\section{INTRODUCTION}

Parturition is a natural process, which can take a turn making it 'lethal' for any patient. Pregnancy and childbirth is a Universally celebrated event. Yet for many women, it is a tortuous journey that may end in death. ${ }^{1} \mathrm{~A}$ woman dies as a result of complication arising during pregnancy and childbirth every 90 seconds in the world, and every 7 minutes in India. ${ }^{2}$ The majority of these deaths are avoidable. Maternal health is a very sensitive issue which has not only affected on the social and economic development of a country but also on the rights of the highest attainable standard of health of an individual.

Maternal mortality - According to WHO "The death of a woman during pregnancy or within 42 days of termination of pregnancy, irrespective of the duration and site of the pregnancy, from any cause related to or aggravated by the pregnancy or its management but not from accidental or incidental causes". ${ }^{3}$

Everyday approximately 830 women die from preventable cause of maternal mortality. $99 \%$ of all 
maternal deaths occur in developing countries. ${ }^{4}$ Globally, there were an estimated 303,000 maternal deaths in 2015, a decline of $44 \%$ from $1990 .{ }^{5}$ Maternal death audit - it is an in-depth systematic review of maternal deaths to describe their underlying health social and other contributory factors, and the lessons learned from such an audit are used in making recommendations to prevent similar future deaths. Although this audit process empowers local authorities to understand and helps to take steps to improve maternal health. ${ }^{6}$ Each year in India, roughly 28 million women experience pregnancy and 26 million have a live birth. Of these, an estimated 67,000 maternal deaths and one million new-born deaths occur each year. ${ }^{7}$ Hence, it is important to evaluate the spectrum of causes behind this large number of maternal deaths in our country. Hence the present study has been undertaken to evaluate the causes, risk factors associated with maternal mortality and to find out the measures which can be taken to reduce maternal mortality.

\section{METHODS}

This study will include retrospective analysis of all maternal deaths occurred in department of obstetrics and gynaecology of tertiary care hospital from July 2010 to June 2016.

The study commenced after the approval of institutional ethics committee.

Data regarding maternal mortality will be documented from maternal mortality register after obtaining permission.

\section{Inclusion criteria}

- All pregnant women irrespective of gestational age and postpartum within 42 days of delivery registered or unregistered who died due to direct or indirect causes in tertiary care hospital will be included in the study

- Death due to ectopic pregnancy.

\section{Exclusion criteria}

- Coincidental maternal deaths like suicide and accidental deaths.

All cases of maternal mortality between July 2010 to June 2016 will be included in the study. Thorough analysis of the individual case record of all the cases of maternal mortality will be undertaken and data will be analysed.

\section{Statistical analysis}

Being a retrospective observational study, frequency and percentage calculations were used in the statistical analysis.
Maternal mortality ratio will be calculated by using the formula:

$$
\text { MMR }=\frac{\text { Total no of maternal deaths } \times 100000}{\text { Total no of livebirths }}
$$

\section{RESULTS}

Table 1: Age distribution.

\begin{tabular}{|lll|}
\hline Age (years) & $\begin{array}{l}\text { No. of patients } \\
(\mathbf{n = 3 8 2})\end{array}$ & $\begin{array}{l}\text { \% of } \\
\text { patients }\end{array}$ \\
\hline$<$ or $=20$ & 31 & 8.1 \\
\hline $21-25$ & 163 & 42.7 \\
\hline $26-30$ & 138 & 36.1 \\
\hline $31-35$ & 37 & 9.7 \\
\hline$>35$ & 13 & 3.5 \\
\hline
\end{tabular}

Table 2: Residence.

\begin{tabular}{|lll|}
\hline Residence & $\begin{array}{l}\text { No. of patients } \\
(\mathbf{n}=\mathbf{3 8 2})\end{array}$ & $\begin{array}{l}\text { \% of } \\
\text { patients }\end{array}$ \\
\hline Urban & 313 & 82 \\
\hline Rural & 69 & 18 \\
\hline
\end{tabular}

Table 3: Type of admission.

\begin{tabular}{|lll|}
\hline $\begin{array}{l}\text { Type of } \\
\text { admission }\end{array}$ & $\begin{array}{l}\text { No. of patients } \\
(\mathbf{n}=\mathbf{3 8 2})\end{array}$ & $\begin{array}{l}\text { \% of } \\
\text { patients }\end{array}$ \\
\hline Referred & 289 & 75.6 \\
\hline Direct admission & 93 & 24.3 \\
\hline
\end{tabular}

Table 4: Transportation.

\begin{tabular}{|lll|}
\hline $\begin{array}{l}\text { Free transport } \\
\text { available }\end{array}$ & $\begin{array}{l}\text { No. of patients } \\
(\mathbf{n}=\mathbf{3 8 0})\end{array}$ & $\begin{array}{l}\text { \% of } \\
\text { patients }\end{array}$ \\
\hline Yes & 100 & 26.32 \\
\hline No & 182 & 64.54 \\
\hline Direct admission & 93 & 24.47 \\
\hline Undelivered/abortion/ectopic & 152 & 39.7 \\
\hline
\end{tabular}

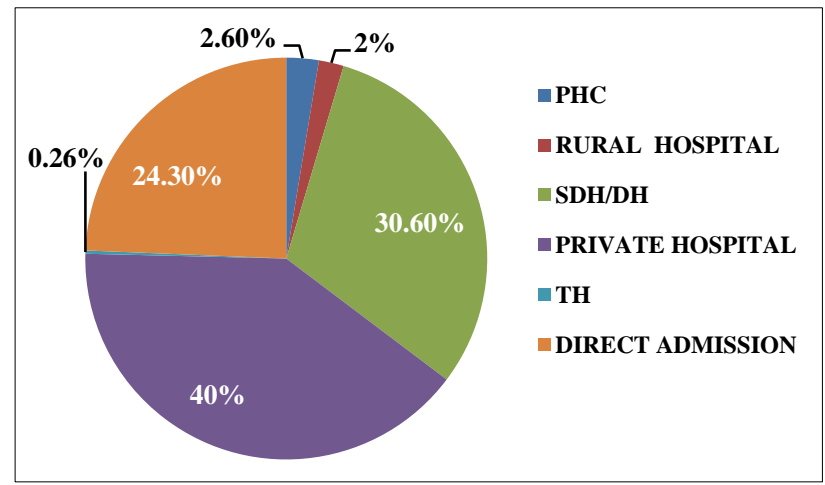

Figure 1: Type of referral facility.

Figure 1 shows when type of facility from where these patients were referred was evaluated, it was found that most of the patients $289(75.6 \%)$ were referred to tertiary 
health centre majority from SDH/DH 117 (30.6\%) and Private hospital $153(40 \%)$.

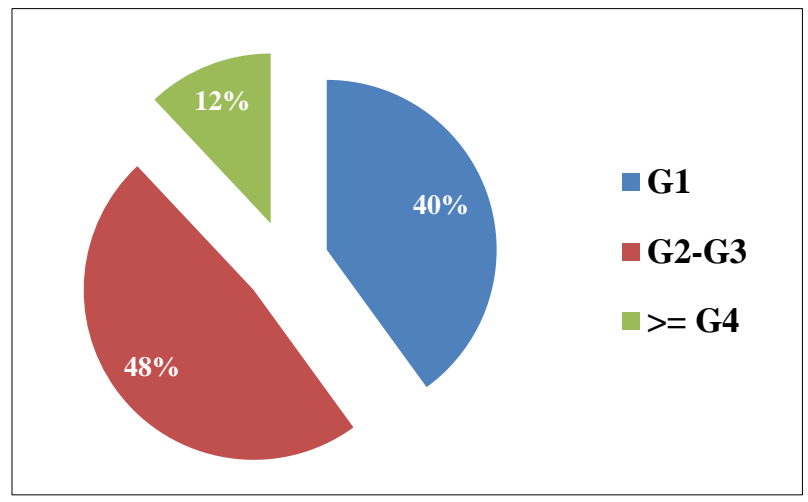

Figure 2: Gravidity.

Figure 2 shows almost half of the women (183) $48 \%$ were multigravida, $40 \%$ (155) women were primigravida and only $12 \%$ (44) women were grandmultipara.
Table 5: Gestational period of death.

\begin{tabular}{|lll|}
\hline Death during & $\begin{array}{l}\text { No. of patients } \\
(\mathbf{n}=\mathbf{3 8 2})\end{array}$ & $\begin{array}{l}\% \text { of } \\
\text { patients }\end{array}$ \\
\hline Ectopic & 6 & 1.6 \\
\hline Antenatal & 109 & 28.5 \\
\hline Postnatal & 230 & 60 \\
\hline Postabortal & 37 & 9.6 \\
\hline
\end{tabular}

Table 6: Mode of delivery.

\begin{tabular}{|lll|}
\hline Mode of delivery & $\begin{array}{l}\text { No. of } \\
\text { patients } \\
(\mathbf{n}=\mathbf{3 8 2})\end{array}$ & $\begin{array}{l}\text { \% of } \\
\text { patients }\end{array}$ \\
\hline Vaginal delivery & 137 & 36 \\
\hline Operative vaginal delivery & 18 & 5 \\
\hline LSCS & 71 & 18.5 \\
\hline Classical caesarean section & 2 & 0.5 \\
\hline
\end{tabular}

Table 7: Intervention.

\begin{tabular}{|lll|}
\hline Operative procedure done & $\begin{array}{l}\text { No. of patients } \\
\text { (n=382) }\end{array}$ & \begin{tabular}{c} 
\% of patients \\
\hline Exploratory laparotomy for perforative peritonitis, uterinerupture, hemoperitoneum
\end{tabular} \\
\hline Exploratory laparotomy with unilateral salpingectomy & 10 & 2.6 \\
\hline Exploratory laparotomy with obstetric hystetrectomy & 6 & 1.57 \\
\hline Classical caesarean section with obstetric hysterectomy & 6 & 1.57 \\
\hline Classical caesarean section & 1 & 0.26 \\
\hline Lower segment caesarean section & 71 & 0.26 \\
\hline BMV & 5 & 18.5 \\
\hline Not required & 283 & 1.31 \\
\hline
\end{tabular}

Table 8: Direct causes of maternal mortality.

\begin{tabular}{|c|c|c|c|}
\hline Direct causes of maternal mortality & & $\begin{array}{l}\text { No. of patients } \\
(\mathrm{n}=\mathbf{3 8 2})\end{array}$ & $\%$ of patients \\
\hline \multicolumn{4}{|l|}{ Group name/number } \\
\hline \multirow{2}{*}{$\begin{array}{l}\text { Pregnancies with abortive } \\
\text { outcome/ectopic/miscarriage }\end{array}$} & Ectopic & 6 & 1.57 \\
\hline & Abortion & 11 & 2.87 \\
\hline \multirow{3}{*}{$\begin{array}{l}\text { Hypertensive disorders in pregnancy, childbirth, } \\
\text { and the puerperium }\end{array}$} & Preclampsia & 9 & 2.3 \\
\hline & Eclampsia & 28 & 7.3 \\
\hline & HELLLP & 9 & 2.3 \\
\hline Obstetric haemorrhage & & 42 & 11 \\
\hline Pregnancy-related infection & & 20 & 5.6 \\
\hline \multirow{5}{*}{ Other obstetric complications } & Acute fatty liver of pregnancy & 13 & 3.4 \\
\hline & Pulmonary embolism & 1 & .26 \\
\hline & Corticovenous sinus thrombosis & 8 & 2 \\
\hline & Peripartum cardiomyopathy & 3 & 0.78 \\
\hline & Hepatorenalsyndrome & 3 & 0.78 \\
\hline Unanticipated complications of management & Anaesthesia related & 0 & 0 \\
\hline \multicolumn{2}{|l|}{ Indirect cause } & 229 & 60 \\
\hline
\end{tabular}

Figure 3 and 4 show that majority of women were registered i.e. $292(76.4 \%)$ and 90 (23.6\%) were unregistered patients. Out of 292 registered patients 194 (51\%) women had more than 3 ANC visits and 75 (20\%) 
women had less than 3 ANC visits. Number of ANC visits of about $2 / 3(6 \%)$ women were not known.

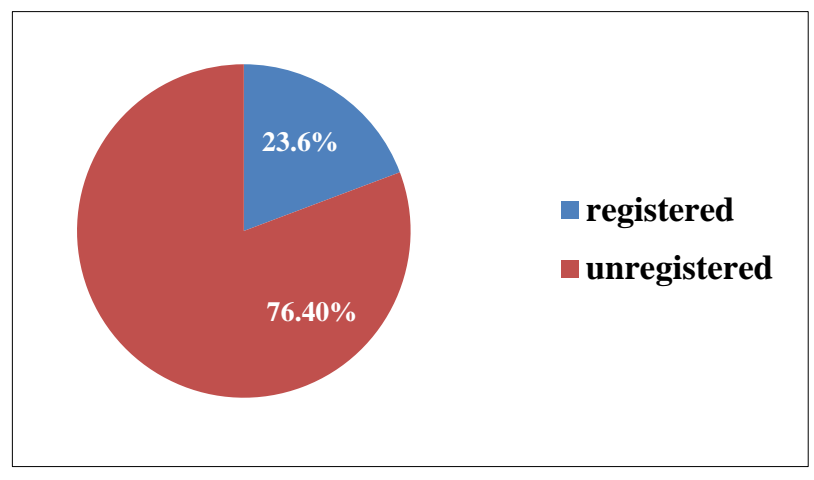

Figure 3: ANC registration.

Table 9: Indirect cause.

\begin{tabular}{|lll|}
\hline Indirect cause & $\begin{array}{l}\text { No. of } \\
\text { patients } \\
(\mathbf{n}=\mathbf{3 8 2})\end{array}$ & $\begin{array}{l}\text { \% of } \\
\text { patients }\end{array}$ \\
\hline Anaemia & 8 & 2 \\
\hline $\begin{array}{l}\text { Respiratory conditions } \\
\text { (except TB and HINI) }\end{array}$ & 22 & 5.75 \\
\hline $\begin{array}{l}\text { Acute febrile illness with } \\
\text { ARDS }\end{array}$ & 5 & \\
\hline Cardiac disease & 25 & 6.5 \\
\hline $\begin{array}{l}\text { Gastro intestinal disease } \\
\text { (except hepatitis E) }\end{array}$ & 11 & 2.8 \\
\hline Endocrine disease & 2 & 0.52 \\
\hline $\begin{array}{l}\text { Central nervous system } \\
\text { conditions (viral } \\
\text { encephalitis + } \\
\text { subchorionic bleed) }\end{array}$ & 15 & 4 \\
\hline Autoimmune disorders & 9 & 2.3 \\
\hline Malignancy & 9 & 2.3 \\
\hline Septicaemia with DIC & 6 & 1.57 \\
\hline Infections & & 11 \\
\hline Tuberculosis & 42 & 8.37 \\
\hline Hepatitis E & 32 & 3.1 \\
\hline Malaria & 12 & 1.8 \\
\hline Dengue & 7 & 0.78 \\
\hline HIV & 3 & 2.8 \\
\hline Leptospirosis & 3 & \\
\hline H1N1 & 11 & \\
\hline Other & & \\
\hline & 5 & \\
\hline
\end{tabular}

\section{DISCUSSION}

Maternal mortality refers to deaths due to complications from pregnancy or childbirth. Complete and accurate identification of all deaths associated with pregnancy is a critical first step in the prevention of such deaths. Reducing the maternal morbidity and mortality is the prime healthcare goal in developing countries. Only by having a clear understanding of the changing trends and the magnitude of pregnancy-related mortality can be comprehensive prevention strategies be formulated to prevent these unanticipated deaths among women.

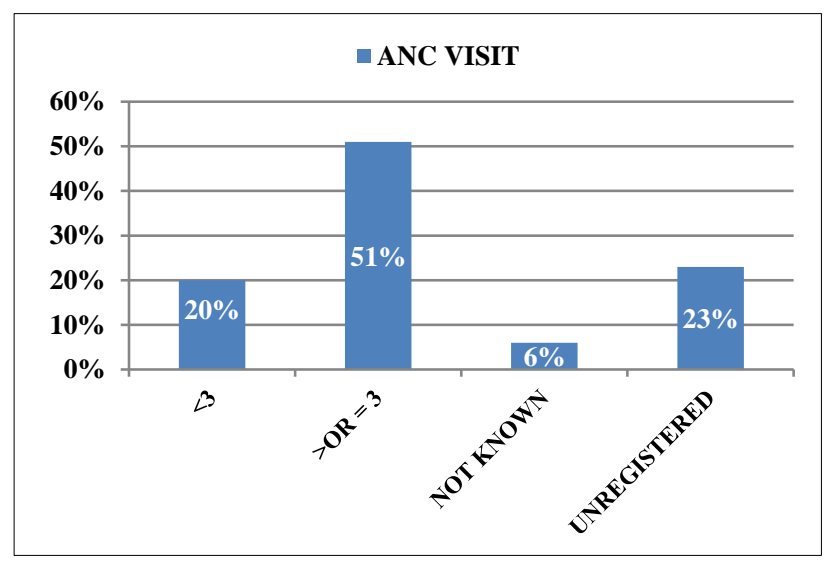

Figure 4: ANC visit.

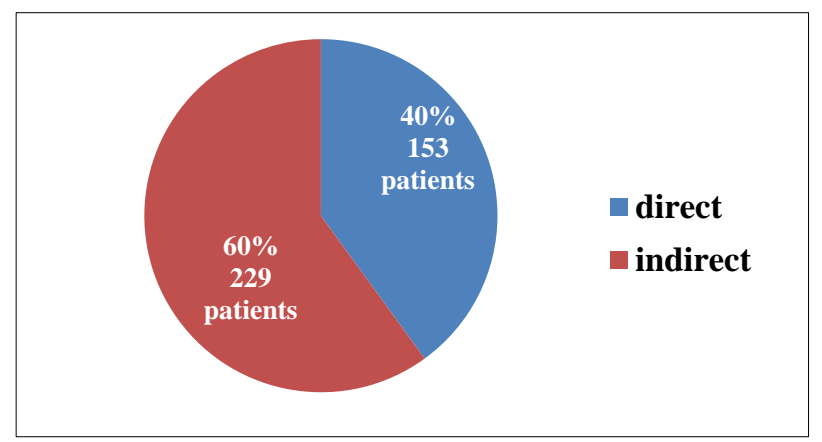

Figure 5: Causes of maternal mortality.

\section{Age distribution}

In present retrospective study of six year duration between July 2010 to June 2016 maximum no. of maternal death $(42.7 \%)$ were in age group of $21-25$ years followed by $36.1 \%$ in age group of $26-30$ years, $8.1 \%$ maternal deaths were seen in age less than 20 years and $3.1 \%$ maternal deaths were seen in age group more than 35 years as shown in Table 1 .

Retrospective study by Mukherjee S, et al observed that maximum deaths $(68 \%)$ occurred in age group of 20 30 years followed by $22 \%$ in more than 30 years while $10 \%$ in age group of less than 20 years. ${ }^{11}$ Shannon Fernandes, et al showed that $64 \%$ maternal deaths were seen in age group of 21-30 years followed by $31 \%$ in age more than 31 years and $5 \%$ in age less than 20 years. ${ }^{12}$

Maximum number of maternal deaths can be attributed to the Indian tradition of early marriages which results in early pregnancy. The reduction in number of deaths in women age $<20$ years of age is partly due to liberalization of abortion law (MTP Act), as a result of which many young women seek help from specialist doctor for legal abortion, thus reducing number of death associated with criminal abortions and its complication. 


\section{Residence}

In present study maximum no of maternal deaths $82 \%$ were of women residing in urban area and rest $18 \%$ came from rural areas as shown in Table 2.

As this study was carried out in tertiary care centre attached to teaching institute of a metropolitan city hence maximum cases belonged to urban area.

\section{Type of admission}

Maximum patients in present study were referred from other hospital to our tertiary care centre in view of higher and specialised treatment with facilities of emergency obstetric care. In present study majority of patients referred from sub-district hospital/district hospital and private hospital. Rest of the patients referred from rural hospital and PHC as shown in Table 3 and Figure1.

Badrinath $\mathrm{M}$ et al observed that $97.4 \%$ patients were referred and $2.6 \%$ patients directly admitted. ${ }^{13}$ Paul et al also observed that $88 \%$ of the patients referred from other health facilities. ${ }^{14}$ Purandare $\mathrm{N}$ et al, observed that out of 30 patient 23 patients were referred from other health care facilities. ${ }^{15}$ Tertiary care centre has the maximum burden of complicated referred cases with potential maternal mortality.

\section{ANC registration}

In present study $292(76.4 \%)$ patients were registered as shown in Figure 3. Out of 292 registered patients 228 patients were referred from other health facilities. Out of 292 registered patients $(51 \%)$ women had more than 3 ANC visits and $20 \%$ women had less than 3 ANC visits. Number of ANC visits of about $23(6 \%)$ women were not known (Figure 4). Similar result were seen in retrospective study conducted by Purandare et al where out of 30 patients 27 women were registered and 3 patients were unregistered. This is in contradiction with other study which observed that maximum number of maternal deaths in unregistered cases. Vidyadhar et al had $71 \%$ unregistered cases. ${ }^{16}$ Zaman observed that out of 58 patients 32 were unregistered, 6 patients had 1 ANC visit, 3 patients had 2 ANC visit and 10 patients had 3 ANC visit and 5 patients had more than 4 ANC visit. ${ }^{17}$ As the present study was carried out in tertiary centre in metropolitan city the number of registered patients were more as compared to other studies. In present study free transportation was provided to only $100(26.3 \%)$ referred patients. While 189 (49\%) referred patients had come with private ambulance/vehicle, free transportation was not available for them (Table 4). Facility of prompt and free transportation for early referral is required.

\section{Gestational period of death}

In present study maximum number of maternal deaths $60 \%$ were seen in postnatal period, followed by
$28.5 \%$ maternal deaths seen in antenatal period. In postabortal period $9.6 \%$ maternal deaths were seen while 6 patients died due to ectopic pregnancy (Table 5). Shobha Mukherjee, et al observed that $47 \%$ maternal deaths were seen in antenatal period, $43 \%$ were seen in postnatal period, $6 \%$ maternal deaths were seen in post-abortal period and $4 \%$ patients died due to ectopic pregnancy. ${ }^{12}$ Zaman $\mathrm{S}$ et al observed that maximum deaths $46 \%$ were during postnatal period, followed by $36 \%$ during antenatal period and $16 \%$ during intranatal period. ${ }^{17}$ Anupamma $\mathrm{N}$ et al observed that $66 \%$ of maternal death were seen in postnatal period and $33 \%$ of maternal deaths were seen in antenatal period. Above study finding is consistent with present study findings while Badrinath $\mathrm{M}$ et al observed that maternal deaths in $1^{\text {st }}, 2^{\text {nd }}, 3^{\text {rd }}$ trimester, intranatal and postnatal period were $4.5 \%$, $13 \%, 40 \%, 4.6 \%$ and $35.5 \%$ respectively. ${ }^{18}$

\section{Gravidity}

In present study almost half of the women $48 \%$ were multigravida, $40 \%$ women were primigravida and only $12 \%$ women were grand-multipara as shown in figure 2 . Retrospective study by Fernandes S observed that $47 \%$ deaths were among primigravida, 50\% deaths among multigravida and $2.5 \%$ deaths were seen in grandmultipara. ${ }^{12}$

Too many and too close pregnancy adversely affect maternal health.

\section{Mode of delivery}

Present study also shows that most of the women $36 \%$ delivered vaginally, $5 \%$ patients underwent operative vaginal delivery, $18.5 \%$ patients had LSCS, $0.5 \%$ patients underwent classical caesarean section. Rest of patients (152) were either undelivered or died due to ectopic or died during post-abortal period (Table 6). Similar result found in retro-prospective study done by Arpita et al study who observed that $47 \%$ patients delivered vaginally, $18 \%$ patients underwent LSCS, $6.7 \%$ patients underwent exploratory laparotomy, 23\% patients undelivered and $10 \%$ were early pregnancy death. ${ }^{19}$ Mundkar and Rai et al observed that out of 66 patients $22 \%$ (15) patients were delivered vaginally, 30.3\% (20) patients underwent LSCS, $4.5 \%$ (3) patients had abortion and $3 \%$ (2) patients died due to ectopic pregnancy and rest 22 patients were undelivered. ${ }^{20}$ Purandare $\mathrm{N}$ et al observed that 7 of the 30 patients died ante partum and 22 postpartum. There was one intrapartum death. Of those that had delivered, 14 had delivered normally, one by forceps extraction, and 7 by cesarean section. 18 of the 22 had live births while 4 had stillbirths. ${ }^{15}$

\section{Operative procedure}

In present study out of 382 maternal deaths 71 patients underwent lower segment caesarean section, 10 patients underwent exploratory laparotomy for perforative 
peritonitis, uterine rupture, hemoperitoneum, 6 patients underwent exploratory laparotomy with unilateral salpingectomy for ruptured ectopic pregnancy, 6 patients underwent exploratory laparotomy with obstetric hystetrectomy, one patient underwent classical caesarean section with obstetric hysterectomy, while one patient underwent only classical caeserean section, and 5 patients underwent balloon mitral valvotomy for heart disease (Table 7).
Arpita $\mathrm{N}$ et al, observed that out of 194 patients 35 patients underwent lower segment caesarean section and 13 patients underwent exploratory laparotomy for ruptured ectopic pregnancy. ${ }^{19}$ Mundkur and Rai observed that 20 out of 62 patients underwent lower segment caesarean section and 2 patients underwent exploratory laparotomy for ruptured ectopic. ${ }^{20}$ An increasing number of operative procedures were performed in the recent years with the intention to save more.

Table 10: Retrospective study of various causes.

\begin{tabular}{|llll|}
\hline Retrospective studies & Haemorrhage & Hypertensive disorder & Sepsis \\
\hline Mundkar and Rai & $20 \%$ & $3.2 \%$ & $17.7 \%$ \\
\hline Badrinath M et al & $26.66 \%$ & $26.66 \%$ & $18.33 \%$ \\
\hline Vidyadhar et al & $21 \%$ & $10.8 \%$ & $7.8 \%$ \\
\hline Fernandes S et al & $26.6 \%$ & $21.43 \%$ & $14.3 \%$ \\
\hline Present study & $11 \%$ & $12 \%$ & $5.6 \%$ \\
\hline
\end{tabular}

\section{Causes of maternal mortality}

In present study majority of maternal deaths $60 \%$ (229) were due to indirect cause while $40 \%$ (153) patients died due to direct cause. Cause of death are divided according to the WHO Application of ICD-10 to deaths during pregnancy, childbirth and the puerperium: ICD-MM.

In present study deaths due to direct causes were $40 \%$ as shown in figure 5 which is divided in 6 groups, Group 1 included deaths due to abortion $2.8 \%$ and deaths due to ruptured ectopic $1.57 \%$. Group 2 included deaths due to preeclampsia $9 \%$, due to eclampsia $28 \%$ and deaths due to HELLP syndrome $9 \%$. Group 3 included deaths due to obstetric hemorrhage were $11 \%$. Group 4 included deaths due to pregnancy related infection were 5.6\%. Group 5 contain deaths due to other obstetric complication like deaths due to acute fatty liver of pregnancy $3.4 \%$, pulmonary embolism $0.26 \%$, cortico venous sinus thrombosis $2 \%$, peripartum cardiomyopathy $3 \%$, and due to hepatorenal syndrome $3 \%$. Group 6 include anaesthesia related death, no such death found in this study. In present study maximum deaths were due to hypertensive disorder followed by obstetric hemorrhage (Table 8). Group 7 include indirect causes. Most common indirect cause of death was tuberculosis 42 cases $(11 \%)$ which is equivalent to death due to obstetric hemorrhage Disseminated tuberculosis, multidrug resistant TB, pulmonary tuberculosis, CNS tuberculoma, tubercular meningitis were the major causes of maternal deaths. Deaths due to hepatitis E were $8.37 \%$ (32). $25(6 \%)$ deaths were due to heart disease which included rheumatic heart disease with pulmonary hypertension and congenital heart disease, $5.75 \%$ deaths were due to respiratory disease which included deaths due to ARDS, respiratory failure with pneumonia. $4 \%$ deaths were due to CNS disorder which included deaths due to viral encephalitis and subarchnoid hemorrage. 12 deaths were due to malaria both falciparum and vivax, 8 deaths were due to anaemia it also included sickle cell crisis.9 deaths were due to autoimmune disorder which included deaths due to SLE, scleroderma. 9 deaths were due to malignancy. ${ }^{7}$ deaths were due to dengue, 7 deaths were due to HINI, 3 deaths were due to HIV and 3 deaths were due to leptospirosis. 12 deaths were due to other causes (Table 9).

According to SRS the leading causes of maternal death in India have been, haemorrhage (38\%), sepsis $(11 \%)$, and abortion (8\%).

According to WHO Between 2003 and 2009, haemorrhage $(27.1 \%)$, hypertensive disorders $(14 \%)$, and sepsis $(10 \%)$ were responsible for more than half of maternal deaths worldwide. More than a quarter of deaths were attributable to indirect.

Various retrospective study conducted in tertiary centre observed that major cause of maternal mortality haemorrhage, hypertensive disorder and sepsis as shown in Table 10. ${ }^{12,13,16,19,20}$ Madhuribadrinath et al, observed that $72.5 \%$ of maternal deaths were due to direct causes. Like hemorrhage (26.66\%), eclampsia (26.66\%), and sepsis $(18.33 \%){ }^{13}$

Vidyadhar et al observed that $50 \%$ maternal deaths were due to direct and $50 \%$ maternal deaths were due to indirect causes. $21 \%$ deaths due to hemorrhage, $10.5 \%$ were due to eclampsia, $10.5 \%$ were due to embolism, $7.8 \%$ were due to sepsis, $21 \%$ were due to hepatitis, $13 \%$ were due to heart disease, $7.8 \%$ were due to cerebral malaria, $5.25 \%$ were due to viral encephalitis and $2.6 \%$ were due to anemia. ${ }^{16}$

Maternal deaths in Mumbai have increased $40 \%$ over the past five years. According to recent news report one of 
the most common cause of maternal deaths in Mumbai is tuberculosis, an infectious disease that is curable. The finding assumes significance given the resurgence of drug-resistant tuberculosis in the city and other parts of the country. Deaths as a result of anaemia. have reduced drastically, but tuberculosis has emerged as the top cause for maternal mortality After tuberculosis, hepatitis A and hepatitis $\mathrm{E}$ (foodborne infections) have killed most pregnant women admitted at hospitals in Mumbai. Earlier, the most common causes for maternal deaths were antepartum and post-partum haemorrhage, preeclampsia, sepsis as a result of infection. This report of Hindustan Times is consistent with our study as our study was also conducted in tertiary hospital of Mumbai. ${ }^{21}$

\section{Maternal mortality ratio}

In the present study of 6-year duration from July 2010 to June 2016 there were 41749 live births and total no. of maternal deaths were 382 . The MMR in the study period was 915/100000 live births which is higher than state and national average.

An estimated 303,000 maternal deaths occurred globally in 2015, yielding an overall MMR of 216 maternal deaths per 100,000 live births from 1990 to 2015, the global maternal mortality ratio declined by 44 per cent - from 385 deaths to 216 deaths per 100,000 live births. $^{5}$

The overall MMR in developing regions is 239 , which is 20 times higher than that of developed regions, where it is just $12 .{ }^{5}$

Almost 99\% maternal deaths occur in developing regions. Two regions, sub-Saharan Africa and South Asia, account for 88 per cent of maternal deaths worldwide. Sub-Saharan Africans suffer from the highest maternal mortality ratio - 546 maternal deaths per 100,000 live births, or 201,000 maternal deaths a year. This is two thirds of all maternal deaths per year worldwide. South Asia follows, with a maternal mortality ratio of 182 , or 66,000 maternal deaths a year, accounting for 22 per cent of the global total. ${ }^{5}$ The national MMR level has come down from 327 per 100,000 live births in 1999-2001 to 167 per 100,000 live births in 2011-13. ${ }^{8}$

Maternal Mortality Ratio (MMR) of India has declined by 16 percent from 212 during 2007-09 to 178 during 2010-12. India's rate of decline of MMR between 200709 and 2011-13 is 5.7 per cent. MMR of Maharashtra had fall from 104 in 2007-09 to 87 in 2010-2012, achieved target of MDG. ${ }^{9}$ In present study high maternal mortality can be due to the fact that the study was conducted in tertiary care referral centre. Admissions of moribund cases referred from rural, sub-district, district and peripheral hospital have inflated this mortality ratio, like other teaching institutions of India. Other similar studies from tertiary care institutions reported MMR range from 270 to 1180 as shown in Table 11.
As this study conducted in tertiary health centre of Mumbai and according to Brihanmumbai Municipal Corporation's (BMC's) health department the total number of deaths in Mumbai has jumped over the last few years with 222 maternal deaths reported during 20102011, 259 in 2011-2012, 278 in 2012-2013 and 260 deaths reported in the first 11 months of the financial year (April 2013 till February 2014). The high incidence of maternal deaths in the city is due to a large number of patients the civic hospitals receive from outside the city (Kalyan, Thane, Navi Mumbai, etc). "If we take maternal deaths of only Mumbai residents, then the MMR reduces to 71 , which meets the millennium development goals". ${ }^{10}$

Table 11: Retrospective studies for MMR.

\begin{tabular}{|ll|}
\hline $\begin{array}{l}\text { Retrospective studies } \\
\text { conducted in tertiary centre }\end{array}$ & $\begin{array}{l}\text { MMR PER 100000 } \\
\text { live birth }\end{array}$ \\
\hline Mukharji S et al & 1180 \\
\hline Suratzaman et al & 709 \\
\hline Arpita N et al & 555.5 \\
\hline Vidhydhar et al & 302 \\
\hline Nishupriya et al & 270 \\
\hline Present study & 915 \\
\hline
\end{tabular}

Many women were referred in moribund state and in irreversible shock and could not be saved even at our tertiary care hospital. Strengthening of the referral units with blood bank, equipment and adequately competent staff for early detection of high risk and timely referral should be of prime importance.

\section{CONCLUSION}

A systematic audit of each and every maternal death should be conducted for the analysis of root cause. The corrective action to prevent the recurrence of such deaths should be taken. In the present study, majority of the maternal deaths were preventable. Hemorrhage, sepsis, PIH, TB, hepatitis E and DIC were found to be the commonest causes for maternal mortality. It important to note that, in the present study, many mothers had received antenatal care, had no teenage pregnancy, had very few obstructed labour or rupture uterus, and yet they died. There is a change in the trend of causes of maternal mortality. Strengthening of the first referral units with equipment, blood bank, and adequately competent staff should be of prime importance. Continued medical education of the medical personnel at the periphery is required. Taking appropriate remedial measures for preventing lapses noted in the management of these cases will be of immense value in reducing the maternal mortality.

\section{ACKNOWLEDGMENTS}

Authors would like to thank Dr Hemangi K. Chaudhari, associate professor KEM Hospital Mumbai and parents 
for their continuous support, immense knowledge and guidance during research work.

Funding: No funding sources

Conflict of interest: None declared

Ethical approval: The study was approved by the Institutional Ethics Committee

\section{REFERENCES}

1. Kaur D, Kaur V, Irene V. Alarmingly high maternal mortality in $21^{\text {st }}$ century. JK Sci. 2007;9(3):123-6.

2. Smith JC, Hughes JM, Pekow PS, Rochat RW. An Assessment of the Incidence of Maternal Mortality in the United States. Am J Pub Health. 1984;74(8):78078.

3. WHO, UNICEF, UNFPA, The World Bank and the United Nations Population Division, Trends in maternal mortality: 1990 to 2013. Estimates Developed by WHO, UNICEF, UNFPA, The World Bank and the United Nations Population Division. Available at: https://www.who.int/reproductive health/publications/monitoring/maternal-mortality2013/en/. Accessed on May 2014.

4. Maternal Mortality. Fact sheet $N^{\circ} 348$. Updated November 2015. Available at: http://www.who.int/mediacentre/factsheets/fs348/en.

5. WHO, UNICEF, UNFPA, The world bank and United Nations Population Division, Trends in maternal mortality: 1990 to 2015. Estimates Developed by WHO, UNICEF, UNFPA, The World Bank and the United Nations Population Division, Available at: https://www.who.int/reproductive health/publications/monitoring/maternal-mortality2015/en/. Accessed on 12 ${ }^{\text {th }}$ November 2015.

6. Mills S. Maternal death audit as a tool. Maternal Death Audit. http://siteresources.worldbank. org/INTPRH/Resources/376374-1278599377733/ MaternalDeathAuditMarch22011.pdf. Accessed on $2^{\text {nd }}$ March 2011.

7. Pathak D, Chakraborty B, Goswami S, Adhikari S. Changing trends of maternal mortality: a comparative study. The J Obstet Gynecol India. 2011:161-5.

8. SAARC Development Goals - India Country Report - 2015. Ministry of statistics and programme implementation. Available at: http://mospi.nic.in/sites/default/files/publication_rep orts/Saarc_IndiaCountryReport-2015_16sep15.pdf. Accessed on $1^{\text {st }}$ September 2015.

9. Reduction in maternal mortality rates amog SCS/STS, Press information bureau Government of India Ministry of health and family welfare. Available at https://pib.gov.in/newsite/PrintRelease .aspx?relid=145156. Accessed on $10^{\text {th }}$ May 2016.
10. Barnagarwala T. City's maternal mortality rate at alarming 158 Civic health dept claims high figure due to patients from outside city. Mumbai News Published; 2014;4:1.

11. Mukherjee S, Mukherjee S, Sarkar R. Six-year retrospective study of maternal mortality at a tertiary teaching institute in Uttar Pradesh. Int J Med Sci Public Health. 2014;3:3.

12. Fernandes S, Prabhu P, D'Cunha P. Maternal mortality at a tertiary care teaching hospital in south India: 10-year retrospective study. Int J Med Health Sci. $2015 ; 4: 3$.

13. Badrinath M, Karekal S. Maternal mortality: a retrospective study. IOSR J Nurs Health Sci. 2015;4(2):10-3.

14. Paul B, Sen M, MohapatraBijeeyani K. Facility based maternal death review: learning from maternal deaths in a teaching hospital of Eastern India. Int $\mathbf{J}$ Biomed Res. 2013;4(1):12-20.

15. Purandare N, Singh A, Upadhyae S, Saraogi R. Maternal mortality at a referral centre: a five year study. J Obstetric Gynaecol India. 2007;57:248-50.

16. Bangal V, Giri P, Garg R. Maternal mortality at a tertiary care teaching hospital of Rural India: a retrospective study. Int $\mathrm{J}$ Biol Med Res. 2011;2(4):1043-6.

17. Zaman S, Begum A. Maternal mortality at a rural medical college of Assam: a retrospective study. J Obstet Gynecol Barpeta. 2014;1(1):46-51.

18. Anupamma N, Nayak S, Kasar P, Sahu B. Maternal death review: an approach towards improving maternal health. J Evol Med Dent Sci. 2014;3(53):12316-26.

19. Yadav K, Namdeo A, Bhargava M. A retrospective and prospective study of maternal mortality in rural tertiary care hospital of central India. Indian J Comm Health. 2013;25:1.

20. Mundkur A, Rai L. Prepare and prevent rather than repair and repent: study of maternal mortality in tertiary care hospital. Int $\mathrm{J}$ Med Pub Health. 2013;3(3):163-7.

21. Vora P, Mumbai: Since 2010, $40 \%$ rise in maternal deaths; TB top killer Hindustan Times, Mumbai. Available at: https://www.hindustantimes.com /mumbai/mumbai-since-2010-40-rise-in-maternaldeaths-tb-top-killer/story-qu4FAge $17 \mathrm{fx} 5 \mathrm{c} 2 \mathrm{~K}$ UinhaxH.html. Accessed on 23rd May 2015.

Cite this article as: Agrawal N, Chaudhari HK. Audit on maternal mortality in a tertiary care centre in India of 6 years, a retrospective analysis. Int $\mathbf{J}$ Reprod Contracept Obstet Gynecol 2020;9:499-506. 